\title{
Dapatkah Pengungkapan Tanggung Jawab Sosial Memoderasi Pengaruh Koneksi Politik dan Kepemilikan Manajerial Terhadap Agresivitas Pajak?
}

\author{
Andre Sumingtio ${ }^{1}$ \\ Estralita Trisnawati ${ }^{2}$ \\ Amrie Firmansyah ${ }^{3}$ \\ 1,2Fakultas Ekonomi dan Bisnis Universitas Tarumanagara, Indonesia \\ ${ }^{3}$ Politeknik Keuangan Negara STAN, Indonesia \\ *Correspondences : andresumingtio@gmail.com
}

\begin{abstract}
ABSTRAK
Koneksi politik yang dimiliki perusahaan menjadi motivasi untuk melakukan agresivitas pajak dengan mengurangi biaya politik dan memilih pihak yang memiliki kedekatan khusus dengan pemerintah. Tujuan penelitian ini adalah untuk mengetahui pengaruh koneksi politik, kepemilikan manajerial dan pengungkapan tata kelola terhadap agresivitas pajak dengan pengungkapan tanggung jawab sosial sebagai variabel moderasi. Data penelitian menggunakan perusahaan sektor barang non konsumsi yang terdaftar di Bursa Efek Indonesia periode tahun 2016-2019 dan diperoleh sejumlah 148 amatan. Alat analisis data yang digunakan adalah software Wrap Partial Least Square (PLS) 7.0. Berdasarkan hasil penelitian, diketahui bahwa variabel moderasi pengungkapan tanggung jawab sosial mampu memoderasi pengaruh koneksi politik dan kepemilikan manajerial, dan kepemilikan manajerial terhadap agresivitas pajak.
\end{abstract}

Kata Kunci: Agresivitas Pajak; Koneksi Politik; Kepemilikan Manajerial; Pengungkapan Tata Kelola; Pengungkapan Tanggung Jawab Sosial.

\section{Can Disclosure of Social Responsibility Moderate the Effect of Political Connections and Managerial Ownership on Tax Aggressiveness?}

\section{ABSTRACT}

The political connections owned by the company become the motivation to carry out tax aggressiveness by reducing political costs and choosing parties who have special affinity with the government. The purpose of this study was to determine the effect of political connections, managerial ownership and disclosure of governance on tax aggressiveness with disclosure of social responsibility as a moderating variable. The research data uses non-consumer goods sector companies listed on the Indonesia Stock Exchange for the 2016-2019 period and obtained a total of 148 observations. The data analysis tool used is Wrap Partial Least Square (PLS) 7.0 software. Based on the results of the study, it is known that the moderating variable of social responsibility disclosure is able to moderate the effect of political connections and managerial ownership, and managerial ownership on tax aggressiveness.

Keywords: $\quad$ Tax Aggressiveness; Political Connections; Managerial Ownership; Good Corporate Governance; Corporate Social Responsibility.

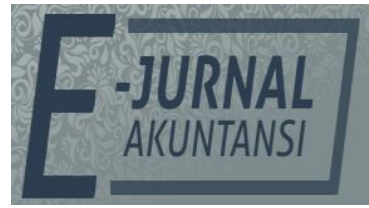

e-ISSN 2302-8556

Vol. 32 No. 2

Denpasar, Februari 2022

Hal. 338-355

DOI:

10.24843/EJA.2022.v32.i02.p05

PENGUTIPAN:

Sumingtio, A., Trisnawati, E. \& Firmansyah, A. (2022). Dapatkah Pengungkapan Tanggung Jawab Sosial Memoderasi Pengaruh Koneksi Politik dan Kepemilikan Manajerial Terhadap Agresivitas Pajak?. E-Jurnal Akuntansi, $32(2), 338-355$

RIWAYAT ARTIKEL:

Artikel Masuk:

9 November 2021

Artikel Diterima: 18 Januari 2022

Artikel dapat diakses : https://ojs.unud.ac.id/index.php/Akuntansi/index 


\section{PENDAHULUAN}

Pajak merupakan sumber pendapatan terbesar bagi negara dimana pajak memegang peranan penting bagi perekonomian sebuah negara terutama Indonesia (Martinus et al., 2021). Oleh karena itu, pajak harus mendapat perhatian khusus dalam hal pelaksanaan, pengumpulan, dan perundang-undangan yang berlaku Kusumawati \& Hardiningsih (2016). Kasus penghindaran pajak yang terjadi di tahun 2019 dilakukan oleh PT. A yang melakukan praktik penghindaran pajak. PT. A diduga melakukan praktik penghindaran pajak dengan melakukan transfer pricing yaitu dengan memindahkan keuntungan dalam jumlah besar dari Indonesia ke perusahaan di negara yang dapat membebaskan pajak atau memiliki tarif pajak yang rendah, hal tersebut dilakukan sejak tahun 2009 hingga 2017. PT. A diduga telah melakukan praktik tersebut sehingga perusahaan dapat membayar pajak sebesar Rp 1,75 triliun atau sebesar US\$ 125 juta lebih rendah dibandingkan jumlah yang seharusnya dibayarkan di Indonesia. Berdasarkan kasus tersebut, pengindaran pajak yang dilakukan yaitu dengan cara melakukan transfer pricing. Dari uraian fenomena di atas yang terjadi diduga bahwa agresivitas pajak masih kerap dilakukan dimana dapat dilihat pada Gambar 1 bahwa tax ratio Indonesia dibandingkan dengan negara asia sebagai berikut.

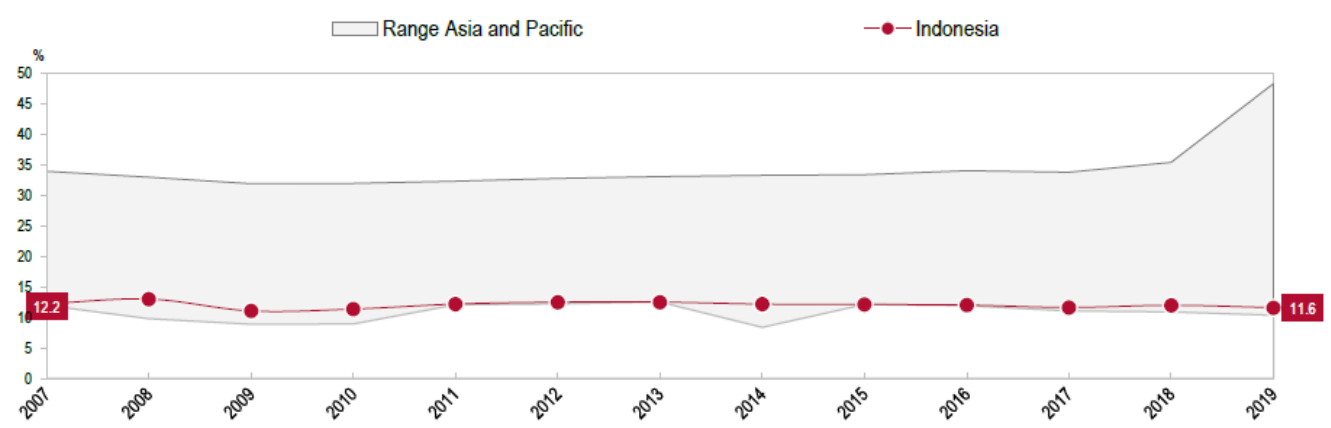

Gambar 1. Tax Ratio Indonesia

Sumber: OECD (2021)

Berdasarkan perkembangan tax ratio, terlihat kecenderungan penurunan tax ratio dari 2007 sampai dengan 2019 dan tax ratio Indonesia dibandingkan dengan negara ASEAN masih sangat rendah (OECD, 2021). Pada tahun 2016, tax ratio Indonesia masih berkisar antara 11-14 persen. Tax ratio Indonesia mengalami penurunan sebesar 0,4 persen dari 12 persen di tahun 2018 menjadi 11,6\% di tahun 2019. Tax ratio tertinggi di Indonesia sebesar 13,0 persen pada tahun 2008 dan terendah sebesar 11,0 persen pada tahun 2009. Masih rendahnya tax ratio memberikan peluang untuk program intensifikasi dan ekstensifikasi perpajakan. Kasus agresivitas pajak di atas menunjukkan bahwa sebagian besar tindakan tersebut dimotivasi oleh usaha perusahaan dalam melakukan agresivitas pajak dan menghemat pengeluaran dari sektor perpajakan supaya mengurangi biaya yang dikeluarkan dan menaikkan laba perusahaan.

Praktik agresivitas pajak yang dilakukan perusahaan tidak terlepas dari faktor-faktor yang mempengaruhinya. Penelitian tentang faktor-faktor yang mempengaruhi praktik penghindaran pajak secara agresif telah dilakukan baik di level internasional maupun di Indonesia. Penelitian yang dilakukan di level internasional antara lain oleh Ortaz \& Alvarez (2020) menguji tentang hubungan 
antara corporate social responsibility dan tax aggressiveness dengan variabel moderating national culture. Selain itu, Sari \& Tjen (2016) menguji tentang corporate social responsibility disclosure, environmental, performance terhadap tax aggressiveness dengan variabel moderating environmental performance yang menyatakan bahwa corporate social responsibility performance berpengaruh negatif terhadap agresivitas pajak. Selanjutnya, Mgbame et al. (2017) menguji perbedaan demografis dalam dewan direksi dan perencanaan pajak pada perusahaan di Amerika dengan variabel dependen board gender diversity, komisaris independen, board size, ROA, dan firm size yang menunjukkan menunjukkan corporate social responsibility berpengaruh negatif terhadap agresivitas pajak.

Sadjiarto et al. (2019) menguji pengaruh political connections dan corporate governance pada tax aggressiveness pada sektor jasa dan perbankan di Indonesia. Iswari et al. (2019) menguji pengaruh political connections in board directors and board commissioners terhadap tax aggressiveness dan menyimpulkan bahwa koneksi politik tidak berpengaruh terhadap agresivitas pajak. Anggraini \& Widarjo (2020) menguji pengaruh political connection, institutional ownership terhadap tax aggressiveness di Indonesia. Wahab et al. (2017) menguji pengaruh political connections dan corporate governance terhadap tax aggressiveness dan menemukan bahwa koneksi politik berpengaruh positif terhadap agresivitas pajak. Novitasari et al. (2017) menguji pengaruh manajemen laba, good corporate governance, dan intensitas modal terhadap agresivitas pajak. Hasil penelitian ini menunjukkan bahwa manajemen laba berpengaruh positif terhadap agresivitas pajak, sedangkan kepemilikan manajerial tidak berpengaruh terhadap agresivitas pajak,

Berdasarkan uraian penelitian terdahulu di atas, maka penelitian empiris untuk membahas pengaruh koneksi politik dan kepemilikan manajerial, dan pengungkapan tata kelola terhadap agresivitas pajak dengan pengungkapan tanggung jawab sosial sebagai variabel moderating dalam satu model belum pernah dilakukan penelitian di Indonesia. Selain itu, variabel-variabel tersebut dipilih karena masih memberikan hasil yang beragam dan belum konsisten pada penelitian terdahulu sehingga diperlukan penelitian lebih lanjut.

Teori akuntansi positif menyatakan bahwa tujuan dari teori akuntansi positif adalah untuk menjelaskan dan memprediksi praktik-praktik akuntansi (Watts \& Zimmerman, 1990). Pengertian dari menjelaskan adalah memberikan dan menyediakan alasan-alasan untuk praktik akuntansi yang dapat diamati, sedangkan pengertian dari memprediksi adalah bahwa teori akuntansi berusaha memprediksi fenomena yang belum diamati. Teori akuntansi positif berusaha menguji tiga hipotesis, yaitu hipotesis program bonus (bonus plan hypothesis), hipotesis hutang/ekuitas (debt/equity hypothesis), dan hipotesis biaya politik (political cost hypothesis). Biaya politik yang dimiliki perusahan menjadi motivasi untuk melakukan agresivitas pajak dengan cara menangguhkan laba tahun sekarang ke laba tahun depan untuk melakukan penghindaran biaya politik sehingga beban pajak yang dibayarkan perusahaan lebih sedikit.

Selanjutnya, teori agensi menjelaskan tentang kontrak di mana satu atau lebih orang (prinsipal) melibatkan orang lain (agen), dimana agen ditugaskan untuk melakukan beberapa pekerjaan atas nama prinsipal yang melibatkan pendelegasian beberapa otoritas pengambilan keputusan kepada agen (Jensen \& Meckling, 1976). Menurut Ross et al. (2016), teori keagenan menjelaskan hubungan 
yang terjadi antara pemegang saham dan manajemen, dimana pemegang saham sebagai principal mempekerjakan orang lain sebagai manajemen (agent) yang bertindak untuk mewakili kepentingannya..

Menurut Freeman (1984), teori stakeholder merupakan teori yang menggambarkan kepada pihak mana saja (stakeholder) perusahaan bertanggung jawab. Keberadaan suatu perusahaan sangat dipengaruhi oleh dukungan yang diberikan oleh stakeholder kepada perusahaan tersebut. Perusahaan diharapkan tidak melakukan tindakan agresivitas pajak dan menjalankan kewajiban pembayaran pajaknya dengan baik. Kondisi ini mendorong hubungan yang baik dengan pihak stakeholder.

Berdasarkan kaitan antara variabel-variabel yang sudah dipaparkan diatas, maka penelitian ini mengambil variabel agresivitas pajak sebagai variabel dependen; variabel koneksi politik, kepemilikan manajerial, dan pengungkapan tata kelola sebagai variabel independen, variabel pengungkapan tanggung jawab sosial sebagai variabel moderasi, serta variabel profitabilitas dan leverage sebagai variabel kontrol dengan kerangka pemikiran pada Gambar 2:

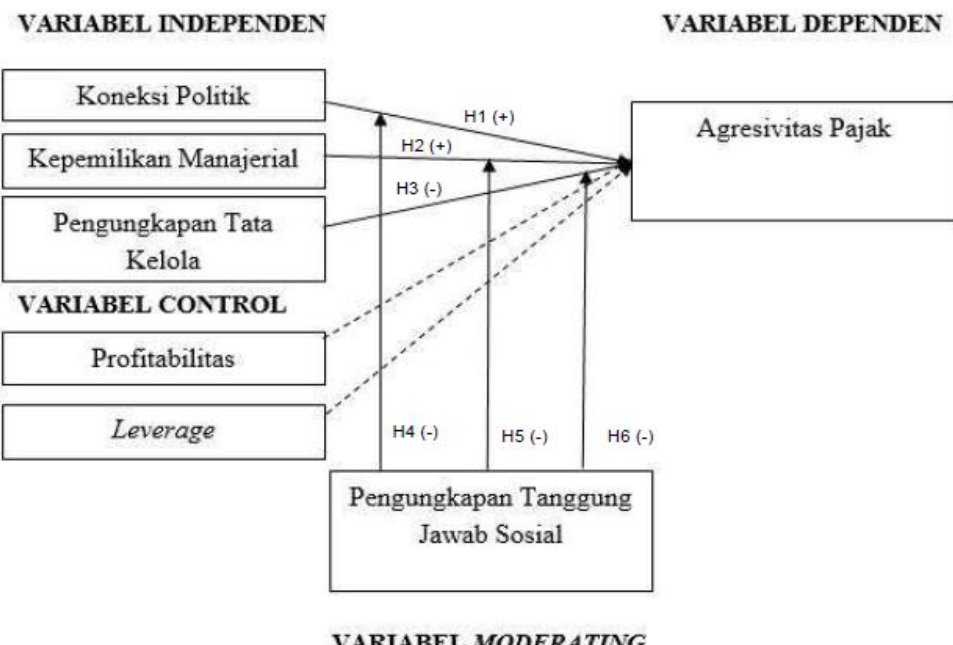

\section{Gunnue}

\section{Kerangka Pemikiran}

Sumber: Data Penelitian, 2021

Penelitian mengenai pengaruh koneksi politik dan agresivitas pajak telah dilakukan oleh Kim \& Zhang (2016). Penelitian tersebut menyimpulkan bahwa perusahaan dengan koneksi politik lebih agresif terhadap pajak karena dengan memiliki koneksi politik, perusahaan tersebut mempunyai risiko deteksi yang rendah, memiliki informasi yang lebih mengenai perubahan-perubahan dalam peraturan perpajakan, tekanan dari pasar modal dalam melakukan transparansi lebih kecil, dapat menurunkan biaya politik yang terkait dengan perencanaan pajak agresif dan kecenderungan untuk mengambil keputusan dengan risiko yang lebih tinggi. Penelitian lainnya oleh Iswari et al. (2019), menunjukkan bahwa koneksi politik berpengaruh negatif terhadap agresivitas pajak. Selain itu, Wicaksono (2017), mengungkapkan bahwa koneksi politik melalui hubungan komisaris berpengaruh positif terhadap agresivitas pajak. Perusahaan yang memiliki koneksi politik umumnya sering melakukan penghindaran pajak. Keadaan ini dilakukan perusahaan agar memiliki risiko deteksi yang lebih rendah 
karena politisi juga memberikan perlindungan terhadap perusahaan yang terhubung dengannya. Dengan demikian, hipotesis pertama dari penelitian ini adalah

$\mathrm{H}_{1}$ : Koneksi politik berpengaruh positif terhadap agresivitas pajak.

Permasalahan keagenan tidak sepenuhnya dapat diatasi melalui kebijakan insentif tetapi diperlukan juga kebijakan baru melalui peningkatan kepemilikan manajerial. Perusahaan meningkatkan kepemilikan manajerial dengan mensejajarkan kedudukan manajer dengan pemegang saham sehingga tindakan yang dilakukan sesuai keinginan dan kebaikan pemegang saham termasuk manajer. Kepemilikan saham perusahaan dapat membuat pihak manajemen berhati-hati dalam mengambil suatu tindakan agresivitas pajak, baik melalui perencanaan pajak menggunakan metode yang terklasifikasi atau tidak terklasifikasi. Kepemilikan manajerial diharapkan dapat membuat pihak manajemen untuk mengesampingkan kepentingan pribadi agar tidak terjadi agresivitas pajak. Keadaan ini menyimpulkan bahwa kepemilikan saham oleh manajerial pada suatu perusahaan dapat mempengaruhi terjadinya agresivitas pajak. Dengan demikian, hipotesis kedua dari penelitian ini adalah.

$\mathrm{H}_{2}$ : Kepemilikan manajerial berpengaruh positif terhadap agresivitas pajak.

Menurut Winata (2014), menyatakan bahwa dengan banyaknya komisaris independen yang dimiliki perusahaan, kesempatan manajer untuk berlaku agresif terhadap pajak juga akan berkurang sehingga tingkat agresivitas pajak perusahaan akan semakin rendah yang digambarkan dengan nilai Effective Tax Rate perusahaan yang tinggi. Hasil penelitian Prima \& Pratiwi (2015), menunjukkan terdapat pengaruh negatif corporate governance terhadap agresivitas pajak. Penelitian dari Sari, (2017) menyimpulkan bahwa terdapat pengaruh negatif corporate governance terhadap agresivitas pajak. Penelitian ini sejalan dengan penelitian dari Abidin et al. (2019) menemukan bahwa terdapat pengaruh negatif corporate governance terhadap agresivitas pajak. Perusahaan yang memiliki tata kelola baik tidak menjamin bahwa perusahaan tersebut tidak melakukan tindakan agresif terhadap pajak. Koordinasi antar anggota dewan menyebabkan penyampaian informasi antar anggota dewan tidak sepaham sehingga tugas dan fungsi dari dewan komisaris tidak berjalan sebagaimana mestinya. Kondisi ini dapat dimanfaatkan oleh pihak manajemen untuk melakukan aksi kecurangannya seperti tidak melaporkan informasi yang seharusnya dilaporkan. Konflik kepentingan yang terjadi di dalam perusahaan dapat dimininumkan dengan adanya dewan direksi yang melaksanakan prinsip-prinsip dalam pengungkapan tata kelola, sehingga banyak dewan direksi dalam perusahaan dapat meminimumkan tindakan pajak agresif. Dengan demikian, hipotesis ketiga dari penelitian ini adalah.

$\mathrm{H}_{3}$ : Pengungkapan tata kelola berpengaruh negatif terhadap agresivitas pajak.

Menurut Fontaine et al. (2006), kelompok utama stakeholder adalah pelanggan, pekerja, komunitas lokal, pemasok dan distributor, dan pemegang saham. Dengan demikian, keberadaan suatu perusahaan sangat dipengaruhi oleh dukungan yang diberikan oleh stakeholder kepada perusahaan tersebut Ghozali \& Chariri (2007). Pengungkapan tanggung jawab sosial terdapat dalam laporan tanggung jawab sosial perusahaan, laporan sumber daya manusia, laporan kesehatan dan keselamatan kerja. Hasil penelitian dari Adhikari et al. (2006), 
Asadanie \& Venusita (2020), dan Tehupuring \& Rossa (2016), menunjukkan bahwa koneksi politik berpengaruh negatif terhadap tax avoidance. Penelitian selanjutnya yaitu Lanis \& Richardson (2013), Hidayat et al. (2018) dan Aalin (2018), menujukkan bahwa corporate social responsibility berpengaruh positif terhadap agresivitas pajak. Perusahaan yang menerapkan corporate social responsibility mempunyai nama baik di mata stakeholder, masyarakat dan pemerintah, serta meningkatkan nilai dan dampak positif dari pengungkapan tanggung jawab sosial yang telah dilakukan oleh perusahaan tersebut. Dengan demikian, hipotesis keempat dari penelitian ini adalah.

$\mathrm{H}_{4}$ : Pengungkapan tanggung jawab sosial memperlemah pengaruh positif koneksi politik terhadap agresivitas pajak.

Fadhila (2017), menyatakan bahwa kepemilikan manajerial dipandang sebagai salah satu faktor yang dapat mempengaruhi agresivitas pajak. Kepemilikan manajerial merupakan kepemilikan saham oleh pihak manajemen, dimana pihak manajemen secara aktif ikut terlibat dalam pengambilan keputusan perusahaan. Selain itu, kepemilikan manajerial juga didefinisikan sebagai kepemilikan saham biasa oleh insider atau pihak manajemen yang terlibat aktif dalam pengambilan keputusan di dalam perusahaan Tjaraka \& Heru (2013). Pengungkapan tanggung jawab sosial yang didasarkan pada kepemilikan manajerial dapat mendorong adanya perilaku yang dapat meningkatkan agresivitas pajak. Hasil penelitidan dari Sari \& Prihandini (2019), Lubis et al. (2018), dan Wijaya \& Saebani (2019) menyimpulkan bahwa kepemilikan manajerial berpengaruh positif terhadap agresivitas pajak. Penelitian selanjutnya dari Sari \& Tjen (2016) dan Mohanadas et al. (2020) menunjukkan bahwa corporate social responsibility berpengaruh negatif terhadap agresivitas pajak. Tanggung jawab sosial perusahaan mengindikasikan pengendalian perilaku para eksekutif puncak perusahaan untuk melindungi kepentingan pemilik perusahaan (pemegang saham). Pemilik modal mendelegasikan kewenangan atas pengelolaan perusahaan kepada manajer. Kepemilikan manajemen sebagai pengawasan terhadap kebijakan-kebijakan manajer dalam pengambilan keputusan pembayaran pajak agar pendapatan pajak yang diterima pemerintah tidak menimbulkan permasalahan, tidak memperburuk reputasi perusahaan di pandangan para stakeholders dan tidak terjadinya pemberhentian operasi bisnis. Dengan demikian, hipotesis kelima dari penelitian ini adalah

$\mathrm{H}_{5}$ : Pengungkapan tanggung jawab sosial memperlemah pengaruh positif kepemilikan manajerial terhadap agresivitas pajak.

Jao \& Pagalung (2011) menyatakan bahwa terwujudnya keseimbangan pengawasan dan pengendalian pengelolaan perusahaan akan menjadi penghambat bagi manajer untuk membuat kebijakan sesuai kepentingan pribadi serta mendorong terciptanya transparansi, akuntabilitas, responsibilitas, independensi, dan keadilan. Hasil penelitian Seprini, (2016) dan Pradnyawati \& Suprasto (2019), menunjukkan bahwa corporate governance berpengaruh positif terhadap agresivitas pajak. Penelitian selanjutnya dari Ortas \& Álvarez (2020), dan Sari \& Tjen (2016), menunjukkan corporate social responsibility berpengaruh negatif terhadap agresivitas pajak. Penerapan pengungkapan tanggung jawab sosial merupakan salah satu bentuk implementasi dari konsep pengungkapan tata kelola. Pengungkapan tata kelola berpengaruh terhadap pengambilan keputusan 
perusahaan dan kinerja perusahaan untuk mencapai tujuan perusahaan dan kepercayaan dari semua pihak. Dengan demikian, hipotesis keenam dari penelitian ini adalah.

$\mathrm{H}_{6}$ : Pengungkapan tanggung jawab sosial memperkuat pengaruh negatif pengungkapan tata kelola terhadap agresivitas pajak.

\section{METODE PENELITIAN}

Penelitian ini menggunakan data perusahaan sektor barang non konsumsi dengan kode C berdasarkan klasifikasi IDX-IC yang terdaftar di BEI tahun 2016-2019 yang ada di Indonesia. Informasi tentang berapa banyak perusahaan sektor barang non konsumsi yang terdaftar di BEI dapat diperoleh dari www.sahamu.com. Sampel penelitian ini diperoleh dengan menggunakan metode purposive sampling dengan beberapa kriteria seperti perusahaan sektor barang non konsumsi (kode C) yang terdaftar 2016-2019 di BEI per 28 Juli 2021, Perusahaan di-delisting selama periode penelitian, Perusahaan yang terdaftar di BEI setelah 1 Januari 2016, dan Perusahaan yang tidak memiliki data lengkap ditentukan sebagai dasar untuk mengeliminasi populasi untuk memilih sampel penelitian.

Penelitian ini menggunakan agresivitas pajak sebagai variabel terikat. Sementara itu, koneksi politik, kepemilikan manajerial, dan pengungkapan tata kelola sebagai variabel bebas, dan pengungkapan tanggung jawab sosial sebagai variabel pemoderasi. Variabel agresivitas pajak dalam penelitian ini diukur dengan menggunakan proxy Discretionary Permanent Book Tax Differences untuk memperkuat hasil penelitian dengan cara mengurangkan laba sebelum pajak di laporan laba rugi dengan laba kena pajak secara fiskal. Pengukuran Discretionary Permanent Book Tax Differences dapat mencerminkan perusahaan melakukan manajemen laba, penghindaran pajak dan perbedaan wajar antara laporan akuntansi dan laporan fiskal. Proksi Discretionary Permanent Book Tax Differences merupakan perbedaan laba akuntansi dan laba pajak yang dirumuskan sebagai berikut dalam penelitian ini dengan menggunakan rumus dari Trisnawati et al. (2020) sebagai berikut.

PERMDIFFit $=\alpha_{0}+\alpha_{1}$ INT ANGit $+\alpha_{2}$ MIit $+\alpha_{3}$ CSTEit $+\alpha_{4} \Delta N O$ Lit + eit.

Keterangan:

PERMDIFFit $=$ Permanent Difference

INTANG = Intangible Assets

$\mathrm{Mi} \quad=$ Profit $/$ Loss for Non Controlling Interest

CSTE $\quad=$ Current Tax

$\triangle N O L=$ Fiscal Loss Compensation

eit $\quad=$ DTAX

Koneksi politik diukur dengan menggunakan variabel dummy dimana 0 (nol) menyatakan tidak ada koneksi politik melalui direksi perusahaan dan 1 (satu) menyatakan adanya koneksi politik melalui direksi, dewan komisaris dan komite audit perusahaan sebagaimana (Ferdiawan \& Firmansyah, 2017). Menurut Besley \& Brigham (2007) mendefinisikan insider sebagai pejabat perusahaan, para direksi, pemegang saham utama dan semua pihak yang mempunyai informasi dari dalam perusahaan atas operasi perusahaan. Pada penelitian ini, kepemilikan manajerial diukur dengan rumus sebagai berikut. 
Kepemilikan Manajerial $=\frac{\text { Total saham manajemen }}{\text { Total saham beredar }}$

Pengungkapan tata kelola diukur dengan membuat content analysis dengan pemberian nilai skor Abadi \& Gunawan (2014) untuk indikator variabel pengungkapan tata kelola yang dibandingkan dengan indikator dari ASEAN corporate governance scorecard bagian A-E dengan rincian sebagai berikut.

\section{Tabel 1. Indikator dari ASEAN Corporate Governance Scorecard}

\begin{tabular}{cl}
\hline Skor & \multicolumn{1}{c}{ Keterangan } \\
\hline 0 & $\begin{array}{l}\text { Jika Perusahaan tidak memiliki pengungkapan informasi tata kelola } \\
\text { Jika Perusahaan memiliki pengungkapan informasi tata kelola dalam diagram } \\
\text { (figur, tabel, chart) yang menunjukkan satu kata hingga satu kalimat. }\end{array}$ \\
2 & $\begin{array}{l}\text { Jika Perusahaan memiliki pengungkapan informasi tata kelola menunjukkan } \\
\text { dua kata hingga satu paragraf. }\end{array}$ \\
3 & $\begin{array}{l}\text { Jika Perusahaan memiliki pengungkapan informasi tata kelola menunjukkan } \\
\text { dua paragraf hingga tiga paragraf. }\end{array}$ \\
4 & $\begin{array}{l}\text { Jika Perusahaan memiliki pengungkapan informasi tata kelola menunjukkan } \\
\text { empat paragraf hingga lima paragraf. }\end{array}$ \\
5 & $\begin{array}{l}\text { Jika Perusahaan memiliki pengungkapan informasi tata kelola menunjukkan } \\
\text { lebih dari lima paragraf. }\end{array}$ \\
\hline
\end{tabular}

Sumber: ASEAN Capital Markets Forum, 2018

Variabel pengungkapan tanggung jawab sosial dalam penelitian ini diukur dengan menggunakan acuan pada indikator Global Reporting Initiative (GRI) versi 4 yang berjumlah 91 item. Skor yang diberikan didasarkan pada tingkat informasi yang disampaikan dalam laporan pengungkapan tamggung jawab sosial perusahaan sebagaimana Firmansyah \& Estutik (2020). Kriteria dalam pemberian skor tersebut yaitu seperti pada Tabel 2.

Tabel 2. Content Analysis terhadap Indikator Pengungkapan Tanggung Jawab Sosial

\begin{tabular}{cl}
\hline Skor & \multicolumn{1}{c}{ Keterangan } \\
\hline 0 & Perusahaan tidak memberikan penjelasan untuk indikator \\
1 & Perusahaan hanya menyebutkan indikator tanpa adanya penjelasan \\
2 & Perusahaan menyebutkan indikator dan memberikan penjelasan secara singkat \\
3 & $\begin{array}{l}\text { Perusahaan menyebutkan indikator dan memberikan penjelaskan dengan } \\
\text { beberapa detail atau rincian }\end{array}$ \\
4 & Perusahaan menjelaskan indikator secara lengkap dan rinci \\
\hline
\end{tabular}

Sumber: Firmansyah \& Estutik (2020)

Proksi yang digunakan untuk pengukuran pengungkapan tanggung jawab sosial yaitu.

$\mathrm{CSRIj}=\frac{\sum \mathrm{Xn}}{\mathrm{ni}}$.

Keterangan:

CSRIj = Corporate Social Responsibility Disclosure Index perusahaan $\mathrm{j}$

$\sum X_{n}=$ Jumlah pengungkapan tanggung jawab sosial perusahaan pada setiap perusahaan

$\mathrm{Ni}=$ Jumlah item pengungkapan tanggung jawab sosial pada setiap perusahaan

Software yang digunakan dalam penelitian ini adalah alat bantu SEM-PLS (Structural Equation Modelling - Partial Least Square) dengan software WarpPLS 7.0. PLS adalah model persamaan struktural (SEM) yang berbasis komponen atau 
varian. Structural Equation Model (SEM) adalah salah satu bidang kajian statistik yang dapat menguji sebuah rangkaian hubungan yang relatif sulit terukur secara bersamaan. Dalam analisis data, penelitian ini menggunakan statistik deskriptif dan statistik inferensial.

Selanjutnya, untuk melakukan analisis terhadap pengaruh moderasi pengungkapan tanggung jawab sosial yang tercermin dari variabel interaksi dalam hipotesis 1 (satu) sampai dengan 6 (enam), digunakan model sebagai berikut:

PERMDIFFit $=\mathrm{a}+$ B1ConPolit + B2ManOwnit + B3CorGovit + B4CSRit + B5ConPol ${ }^{*}$ CSRit + B6ManOwn ${ }^{*}$ CSRit + B7CorGov ${ }^{*}$ CSRit + B8Prof it + B9Levit + $\varepsilon \mathrm{i}, \mathrm{t}$

Keterangan:

Variabel Utama:

PERMDIFFit $=$ Proksi untuk mengukur agresivitas pajak perusahaan $\mathrm{i}$ tahun $\mathrm{t}$

ConPoli, $\mathrm{t}=$ Koneksi Politik $\mathrm{i}$ tahun $\mathrm{t}$

ManOwni, $\mathrm{t} \quad=$ Kepemilikan Manajerial i tahun $\mathrm{t}$

CorGovi, $\mathrm{t}=$ Pengungkapan tata kelola $\mathrm{i}$ tahun $\mathrm{t}$

CSRi, $\quad=$ Pengungkapan tanggung jawab sosial $\mathrm{i}$ tahun $\mathrm{t}$

$\mathrm{a} \quad=$ Nilai Konstanta

$\varepsilon \mathrm{i}, \mathrm{t} \quad=$ error

Variabel Kontrol:

Profi, $\mathrm{t}=$ Profitabilitas perusahaan $\mathrm{i}$ tahun $\mathrm{t}$

Levi, $\mathrm{t}=$ Leverage perusahaan $\mathrm{i}$ tahun $\mathrm{t}$

\section{HASIL DAN PEMBAHASAN}

Penelitian ini memperoleh sampel sebanyak 37 perusahaan selama empat tahun dengan total observasian sebanyak 148 data observasian. Adapun hasil dari analisis sampel dengan menggunakan purposive sampling dapat ditujukan pada Tabel 3 berikut:

\section{Tabel 3. Kriteria Pemilihan Sampel}

\begin{tabular}{clc}
\hline No. & \multicolumn{1}{c}{ Keterangan } & Jumlah \\
\hline 1 & Perusahaan pertambangan sektor barang non konsumsi (kode C) & 127 \\
& yang terdaftar 2016-2019 di BEI per 28 Juli 2021 & \\
2 & Perusahaan di-delisting selama periode penelitian & 0 \\
3 & Perusahaan yang terdaftar di BEI setelah 1 Januari 2016 & $(68)$ \\
4 & Perusahaan yang tidak memiliki data lengkap & $(22)$ \\
& Jumlah sampel satu tahun & 37 \\
& Periode penelitian & 4 tahun \\
& Jumlah sampel 2016-2019 & 148 \\
\hline
\end{tabular}

Sumber: Data Penelitian (2021)

Statistik deskriptif diperlukan guna memberikan informasi terkait karakteristik variabel-variabel penelitian yaitu nilai minimum, nilai maksimum, dan nilai rata-rata sebanyak 148 data observasi yang diperoleh selama 4 tahun yakni tahun 2016-2019 dengan jumlah sampel perusahaan sebanyak 37 perusahaan. Hasil olah data statistik deskriptif dapat dilihat sebagai berikut. 
Tabel 4. Statistik Deskriptif

\begin{tabular}{|c|c|c|c|c|c|c|c|}
\hline Variabel & $\begin{array}{c}\text { PERM } \\
\text { DIFF }\end{array}$ & $\begin{array}{c}\text { CONP } \\
\text { OL }\end{array}$ & $\begin{array}{l}\text { MAN } \\
\text { OWN }\end{array}$ & $\begin{array}{c}\text { CORPG } \\
\text { OV }\end{array}$ & PROF & LEV & CSR \\
\hline Min & $-1,941$ & $-1,912$ & $-6,438$ & $-0,166$ & $-4,446$ & $-6,419$ & $-1,032$ \\
\hline Max & 2,456 & 2,131 & 1,558 & 5,980 & 2,630 & 0,224 & 1,514 \\
\hline Mean & $-1,619$ & $-0,357$ & $-1,289$ & $-1,261$ & $-1,965$ & $-1,914$ & 0,349 \\
\hline Median & $-0,475$ & 0,334 & 0,225 & $-0,166$ & $-0,024$ & $-0,224$ & 0,241 \\
\hline $\begin{array}{l}\text { Standard } \\
\text { Deviasi }\end{array}$ & 0,604 & 0,573 & 0,679 & 0,316 & 1,080 & 0,346 & 0,678 \\
\hline
\end{tabular}

Berdasarkan Tabel 4 dapat dilihat bahwa nilai rata - rata (mean) variabel agresivitas pajak sebesar 1,619. Nilai median dan standar deviasi dari variabel agresivitas pajak adalah $-0,475$ dan 0,604. Nilai maximum dari agresivitas pajak adalah 2,456 yang diperoleh dari perusahaan Surya Citra Media Tbk. (SCMA) tahun 2016. Nilai minimum dari agresivitas pajak adalah -1,941 yang diperoleh dari perusahaan Pioneerindo Gourmet International Tbk. (PTSP) tahun 2016.

Variabel koneksi politik dinyatakan dalam pemberikan skor 1 untuk perusahaan yang memiliki koneksi politik dan skor 0 untuk perusahaan yang tidak memiliki koneksi politik. Berdasarkan Tabel 4 dapat dilihat bahwa nilai rata - rata dari variabel koneksi politik (CONPOL) sebesar -0,357. Nilai median dan standar deviasi dari variabel koneksi politik adalah 0,334 dan 0,573 . Nilai maximum dari CONPOL adalah 2,131 yang diperoleh dari perusahaan Visi Media Asia Tbk. (VIVA) tahun 2017. Nilai minimum dari INTINVT adalah -1,912 yang diperoleh dari perusahaan Selamat Sempurna Tbk. (SMSM) tahun 2018.

Variabel kepemilikan manajerial tetap dinyatakan dengan rasio antara total saham yang dimiliki manajemen dibandingkan dengan total saham beredar yang dimiliki perusahaan tersebut. Berdasarkan Tabel 4 dapat dilihat bahwa nilai rata - rata dari variabel kepemilikan manajerial (MANOWN) sebesar -1,289. Nilai median dan standar deviasi dari variabel kepemilikan manajerial adalah 0,225 dan 0,573. Nilai maximum dari MANOWN adalah 1,558 yang diperoleh dari perusahaan Sona Topas Tourism Industry Tbk. (SONA) tahun 2017. Nilai minimum dari MANOWN adalah 6,438 yang diperoleh dari perusahaan Mitra Pinasthika Mustika Tbk. (MPMX) tahun 2019.

Variabel pengungkapan tata kelola dinyatakan dengan skor dari indikator variabel pengungkapan tata kelola yang dibandingkan dengan indikator dari ASEAN corporate governance scorecard bagian A-E. Nilai rata - rata dari variabel pengungkapan tata kelola yang dimiliki sebesar $-1,261$. Nilai median dan standar deviasi dari variabel pengungkapan tata kelola adalah 0,166 dan 0,316. Nilai maximum dari CORPGOV adalah 5,980 yang diperoleh dari perusahaan Indospring Tbk. (INDS) tahun 2019. Nilai minimum dari GCG adalah 0,166 yang diperoleh dari perusahaan Multi Prima Sejahtera Tbk. (LPIN) tahun 2017.

Variabel pengungkapan tanggung jawab sosial dinyatakan dengan skor indikator pengungkapan tanggung jawab sosial. Nilai rata - rata dari variabel pengungkapan tanggung jawab sosial yang dimiliki sebesar 0,349. Nilai median dan standar deviasi dari variabel pengungkapan tata kelola adalah 0,241 dan 0,678. Nilai maximum dari pengungkapan tanggung jawab sosial adalah 1.514 yang 
diperoleh dari perusahaan Pembangunan Jaya Ancol Tbk. (PJAA) tahun 2017. Nilai minimum dari CSR adalah 1,032 yang diperoleh dari perusahaan Primarindo Asia Infrastructure Tbk. (BIMA) tahun 2018.

Langkah selanjutnya dalam penelitian ini adalah evaluasi outer model dilakukan melalui 3 kriteria yaitu convergent validity, discriminant validity dan composite reliability. Berikut ini adalah hasil pengolahan datanya sebagai berikut:

\section{Tabel 5. Hasil Outer Model}

\begin{tabular}{|c|c|c|c|c|c|c|}
\hline \multirow{2}{*}{$\begin{array}{l}\text { No } \\
1\end{array}$} & \multirow{2}{*}{$\begin{array}{l}\text { Variabel } \\
\text { CONPOL }\end{array}$} & \multicolumn{2}{|c|}{ Dimensi } & \multirow{2}{*}{$\begin{array}{c}\text { Faktor } \\
\text { Loading }\end{array}$} & \multirow{2}{*}{$\begin{array}{l}\text { AVE } \\
0,652\end{array}$} & \multirow{2}{*}{$\begin{array}{c}\text { CR } \\
0,597\end{array}$} \\
\hline & & $\mathrm{X} 1$ & CONPOL & & & \\
\hline 2 & MANOWN & $\mathrm{X} 2$ & MANOWN & 1,000 & 1,000 & 1,000 \\
\hline 3 & CORPGOV & $\mathrm{X} 3$ & CORPGOV & 1,000 & 1,000 & 1,000 \\
\hline 4 & PROF & CONTROL & PROF & 1,000 & 1,000 & 1,000 \\
\hline 5 & LEV & CONTROL & LEV & 1,000 & 1,000 & 1,000 \\
\hline 6 & CSR & MODERASI & CSR & 1,000 & 1,000 & 1,000 \\
\hline 7 & CSR_CONPOL & & CSR_CONPOL & 1,000 & 1,000 & 1,000 \\
\hline 8 & $\begin{array}{l}\text { CSR_MANOW } \\
\mathrm{N}\end{array}$ & & $\begin{array}{c}\text { CSR_MANOW } \\
\mathrm{N}\end{array}$ & 1,000 & 1,000 & 1,000 \\
\hline 9 & $\begin{array}{l}\text { CSR_CORPGO } \\
\mathrm{V}\end{array}$ & & $\begin{array}{c}\text { CSR_CORPGO } \\
\mathrm{V}\end{array}$ & & & \\
\hline 10 & PERMDIFF & $\mathrm{Y}$ & PERMDIFF & & & \\
\hline
\end{tabular}

Sumber: Data Penelitian, 2021

Tahap penelitian selanjutnya adalah melakukan evaluasi model struktural (inner model) yang meliputi uji kecocokan model (fit model), path coefficient, dan $\mathrm{R}^{2}$. Pada uji kecocokan model terdapat 3 indeks pengujian yaitu Average Path Coefficient (APC), Average R-Squared (ARS) dan Average Varians Factor (AVIF) dengan gambar sebagai berikut.

Model fit and quality indices

Average path coefficient (APC) $=0.212, \mathrm{P}=0.002$

Average $R$-squared (ARS) $=0.604, \mathrm{P}<0.001$

Average block VIF (AVIF) $=1.176$, acceptable if $<=5$, ideally $<=3.3$

Gambar 3. Model Fit and Quality Indices

Sumber: Data Penelitian, 2021

Tabel 6. Uji Kecocokan Model

\begin{tabular}{cccc}
\hline Description & Indeks & Kriteria & Keterangan \\
\hline APC & 0,212 & $\mathrm{P}<0,05$ & Diterima \\
ARS & 0,604 & $\mathrm{P}<0,05$ & Diterima \\
AVIF & 1,176 & $\mathrm{AVIF}<5$ & Diterima \\
\hline
\end{tabular}

Sumber: Data Penelitian, 2021 


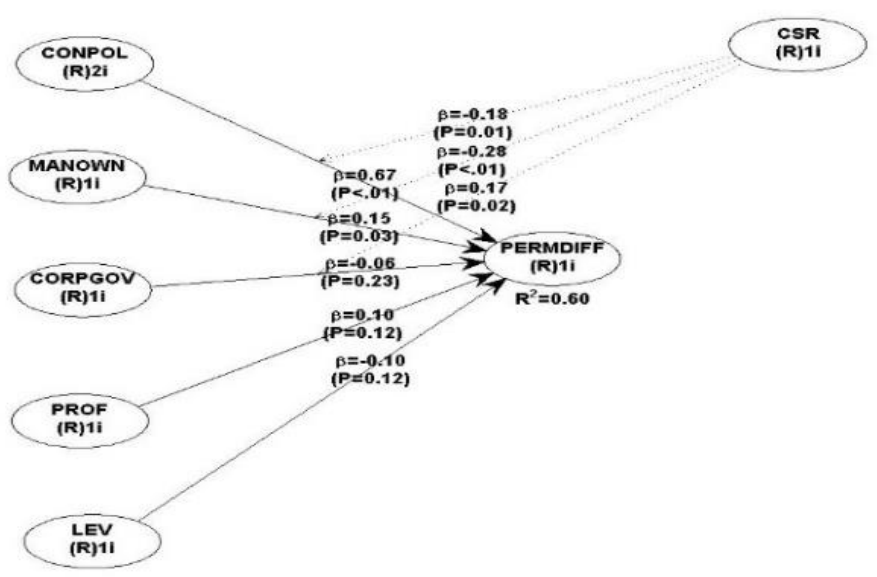

Gambar 4. Model Penelitian

Sumber: Data Penelitian, 2021

Keterangan:

$\begin{array}{ll}\text { PERMDIFF } & =\text { Agresivitas Pajak } \\ \text { ConPol } & =\text { Koneksi Politik } \\ \text { ManOwn }_{i} & =\text { Kepemilikan Manajerial } \\ \text { CorGov } & =\text { Pengungkapan Tata Kelola } \\ \text { CSR } & =\text { Pengungkapan Tanggung Jawab Sosial } \\ \text { Prof } & =\text { Profitabilitas perusahaan } \\ \text { Lev } & =\text { Leverage perusahaan }\end{array}$

Tabel 7. Ringkasan Hasil Pengujian Hipotesis

\begin{tabular}{|c|c|c|c|c|}
\hline Hubungan Antar Variabel & $\begin{array}{c}R- \\
\text { squared }\end{array}$ & $\begin{array}{l}\text { Adj. } R- \\
\text { squared }\end{array}$ & $p$-values & Nilai Beta \\
\hline Koneksi Politik -> Agresivitas Pajak & & & $<0,01$ & 0,67 \\
\hline $\begin{array}{l}\text { Kepemilikan Manajerial -> } \\
\text { Agresivitas Pajak }\end{array}$ & & & 0,03 & 0,15 \\
\hline $\begin{array}{l}\text { Pengungkapan Tata Kelola -> } \\
\text { Agresivitas Pajak }\end{array}$ & & & 0,23 & 0,06 \\
\hline $\begin{array}{l}\text { Koneksi Politik*Pengungkapan } \\
\text { Tanggung Jawab Sosial -> Agresivitas } \\
\text { Pajak } \\
\text { Kepemilikan }\end{array}$ & 0,604 & & 0,01 & 0,18 \\
\hline $\begin{array}{l}\text { Manajerial*Pengungkapan Tanggung } \\
\text { Jawab Sosial -> Agresivitas Pajak } \\
\text { Pengungkapan Tata }\end{array}$ & & 0,582 & $<0,01$ & 0,28 \\
\hline $\begin{array}{l}\text { Kelola*Pengungkapan Tanggung } \\
\text { Jawab Sosial -> Agresivitas Pajak }\end{array}$ & & & 0,02 & 0,17 \\
\hline
\end{tabular}

Sumber: Data Penelitian, 2021

Hasil pengujian hipotesis pertama dalam penelitian ini menunjukkan bahwa koneksi politik tidak berpengaruh terhadap agresivitas pajak. Hasil penelitian ini sejalan dengan penelitian yang telah dilakukan oleh Sadjiarto et al. (2019) dan Iswari et al. (2019). Perusahaan yang memiliki koneksi politik dapat tidak memiliki pengaruh terhadap agresivitas pajak yang diartikan apabila perusahaan tersebut yang memiliki koneksi politik sehingga tidak bisa 
meningkatkan tindakan agresivitas pajak suatu perusahaan. Kondisi tersebut mungkin terjadi karena koneksi politik yang dimiliki komisaris maupun direksi perusahaan sulit untuk melakukan agresivitas pajak karena pajak merupakan kewajiban yang harus dibayarkan oleh setiap wajib pajak.

Hasil pengujian hipotesis kedua dalam penelitian ini menunjukkan bahwa kepemilikan manajerial tidak berpengaruh terhadap agresivitas pajak. Hasil penelitian ini sejalan dengan penelitian Priscilia \& Agoes (2019) dan Utami \& Tahar (2018). Manajemen melakukan cara untuk meningkatkan bonus sebagai manajemen dan deviden sebagai pemegang saham sehingga keputusan untuk kepentingan perusahaan menjadi tidak efektif berpengaruh pada tingkat agresivitas pajak. Kepemilikan manajerial diharapkan dapat membuat pihak manajemen untuk mengurangi aktivitas kepentingan pribadi untuk memperoleh laba yang lebih besar.

Hasil pengujian hipotesis ketiga dalam penelitian ini menunjukkan bahwa pengungkapan tata kelola tidak berpengaruh terhadap agresivitas pajak. Hasil penelitian ini sejalan dengan penelitian yang dilakukan oleh Yunistiyani \& Tahar (2017) dan Sari \& Prihandini (2019). Kemungkinan tidak adanya koordinasi antar anggota dewan menyebabkan penyampaian informasi antar anggota dewan tidak sepaham sehingga tugas dan fungsi dari dewan komisaris tidak berjalan sebagaimana mestinya. Konflik kepentingan yang terjadi di dalam perusahaan dapat dimininumkan dengan adanya dewan direksi yang melaksanakan prinsipprinsip dalam pengungkapan tata kelola, sehingga banyak dewan direksi dalam perusahaan dapat meminimumkan tindakan pajak agresif.

Hasil pengujian hipotesis keempat menunjukkan bahwa pengungkapan tanggung jawab sosial berhasil memperlemah pengaruh positif koneksi politik terhadap agresivitas pajak. Menurut Swingly \& Sukartha (2015), perusahaan sering memanfaatkan stretegi dalam lingkungan bisnis dengan melakukan koneksi politik. Perusahaan yang memiliki koneksi politik cenderung memilih pihak-pihak dalam struktur organisasi baik itu komisaris ataupun direksi perusahaan yang memiliki kedekatan khusus dengan pemerintah. Perusahaan memiliki koneksi politik apabila perusahaan memiliki keterikatan secara politik atau berusaha menjalin hubungan kedekatan dengan politisi atau pemerintah Wati (2017). Perusahaan yang menerapkan pengungkapan tanggung jawab sosial dapat menurunkan tindakan agresivitas pajak akibat adanya koneksi politik yang dimiliki perusahaan. Kondisi ini dapat mencegah kehilangan nama baik perusahaan di mata pemangku kepentingan, masyarakat dan pemerintah. Selain itu, kondisi ini juga mencegah penurunan nilai perusahaan.

Hasil pengujian hipotesis kelima dalam penelitian ini menunjukkan bahwa pengungkapan tanggung jawab sosial memperlemah pengaruh negatif kepemilikan manajerial terhadap agresivitas pajak. Teori stakeholder merupakan sebuah konsep manajemen strategis dengan tujuannya untuk membantu korporasi memperkuat hubungan dengan kelompok-kelompok eksternal dan mengembangkan keunggulan kompetitif (Mardikanto, 2014). Bentuk pertanggungjawaban sosial perusahaan kepada pemangku kepentingan melalui transparansi yang dilakukan oleh perusahaan dalam memenuhi kewajiban perpajakan. Pengungkapan tanggung jawab sosial yang dilakukan oleh perusahaan merupakan suatu hal yang penting karena memberikan dampak 
positif bagi perusahaan dan meningkatkan hubungan perusahaan dengan stakeholder. Kepemilikan saham oleh manajerial dapat idealnya dapat menurunkan tindakan agresivitas pajak. Namun, pengungkapan tanggung jawab sosial malah menurunkan hubungan tersebut. Penerapan pengungkapan tanggung jawab sosial yang dilakukan oleh perusahaan diduga masih hanya sebatas klaim sepihak yang mengandung unsur subyektifitas. Oleh karena itu, peran pengungkapan tanggung jawab sosial masih belum sepenuhnya terlihat dalam hubungan antara kepemilikan manajerial dan agresivitas pajak.

Hasil pengujian hipotesis keenam dalam penelitian ini menunjukkan bahwa pengungkapan tanggung jawab sosial berhasil memperkuat pengaruh negatif pengungkapan tata kelola terhadap agresivitas pajak. Menurut teori stakeholder, kegiatan komunikasi dalam pengungkapan tanggung jawab sosial melibatkan komunikasi perusahaan dengan stakeholder dan sebaliknya komunikasi dari stakeholder kepada perusahaan Supriyono (2011). Salah satu prinsip dari pengungkapan tata kelola adalah responsibilitas. Perusahaan harus mematuhi peraturan perundang-undangan serta melaksanakan tanggung jawab sosial dengan peduli terhadap masyarakat dan kelestarian lingkungan terutama di sekitar perusahaan dengan membuat perencanaan dan pelaksanaan yang memadai sehingga dapat terjadi kesinambungan usaha dalam jangka panjang dan mendapat pengakuan sebagai good corporate citizen. Penerapan pengungkapan tanggung jawab sosial merupakan salah satu bentuk implementasi dari konsep pengungkapan tata kelola. Penerapan pengungkapan tanggung jawab sosial memperkuat peran dari penerapan tata kelola oleh perusahaan (Firmansyah \& Triastie, 2020), sehingga perusahaan akan memiliki tingkat transparansi yang lebih baik dan tanggung jawab untuk menyelaraskan kepentingannya dengan kepentingan pemegang saham. Kondisi ini dapat menurunkan tindakan penghindaran pajak yang agresif.

\section{SIMPULAN}

Koneksi politik, kepemilikan manajerial, dan pengungkapan tata kelola tidak berpengaruh terhadap agresivitas pajak. Selain itu, pengungkapan tanggung jawab memperlemah pengaruh positif koneksi politik terhadap agresivitas pajak, pengungkapan tanggung jawab memperlemah pengaruh negatif kepemilikan manajerial terhadap agresivitas pajak, dan pengungkapan tanggung jawab sosial memperkuat pengaruh negatif pengungkapan tata kelola terhadap agresivitas pajak.

Penelitian ini memiliki beberapa keterbatasan yaitu ruang lingkup yang diuji hanya perusahaan sektor barang non konsumsi dengan kode $C$ berdasarkan klasifikasi IDX-IC yang terdaftar di BEI. Selain itu, horizon waktu yang digunakan selama 4 tahun. Penelitian selanjutnya. Penelitian selanjutnya dapat menggunakan data perusahaan sektor manufaktur dan horizon waktu yang lebih panjang untuk mendapatkan hasil pengujian yang lebih baik. Penelitian selanjutnya juga dapat menggunakan uji regresi linier dengan menggunakan data panel atau ordinary least square.

Penelitian ini mengindikasikan kepada otoritas pajak di Indonesia terkait dengan perbaikan kebijakan perpajakan terutama kebijakan insentif yang diberikan otoritas perpajakan kepada wajib pajak. Selain itu, dalam melakukan 
pemeriksaan terhadap laporan pajak yang dilakukan oleh perusahaan, otoritas perpajakan perlu melihat informasi dalam laporan keuangan dalam mengindektifikasi aktivitas agresivitas pajak yang dilakukan perusahaan.

\section{REFERENSI}

Aalin, E. R. (2018). Pengaruh Pengungkapan Tanggung Jawab Sosial Perusahaan Terhadap Agresivitas Pajak. Jurnal AKSI (Akuntansi Dan Sistem Informasi), 3(2), 82-92. https:// doi.org/10.32486/aksi.v2i2.264

Abadi K. \& Gunawan J. (2014). Content Analysis Method: A Proposed Guideline for Quantitative and Qualitative Disclosures The International Conference on Corporate Governance.

Abidin, M. Z., Askandar, N. S., \& Afifudin. (2019). Pengaruh Good Corporate Governance dsm C. Journal of Chemical Information and Modeling, 53(9), 16891699.

Adhikari, A., Derashid, C., \& Zhang, H. (2006). Public policy, political connections, and effective tax rates: Longitudinal evidence from Malaysia. Journal of Accounting and Public Policy, 25(5), 574-595. https:/ / doi.org/10.1016/J.JACCPUBPOL.2006.07.001

Anggraini, Y., \& Widarjo, W. (2020). Political Connection, Institutional Ownership and Tax Aggressiveness in Indonesia. European Journal of Business and Management Research, 5(5), 1-7. https:/ / doi.org/10.24018/ ejbmr.2020.5.5.528

Asadanie, N. K., \& Venusita, L. (2020). Pengaruh Koneksi Politik terhadap Penghindaran Pajak. INVENTORY : Jurnal Akuntansi, 4(1), 14-21.

ASEAN Capital Markets Forum. (n.d.).

Besley, S., \& Brigham, E. (2007). Essentials of managerial finance. Thomson/Southwestern.

https://books.google.co.id/books?id=oi9sOjf4cv8C\&hl=id\&source=gbs_si milarbooks_r

Fadhila, N. S. (2017). Pengaruh Kepemilikan Manajerial, Komisaris Independen dan Komite Audit Terhadap Tax Avoidance. E-Jurnal Akuntansi, 21(3), 18031820. https://doi.org/10.24843/EJA.2017.v21.i03.p04

Ferdiawan, Y., \& Firmansyah, A. (2017). Pengaruh political connection, foreign activity, dan, real earnings management ter-hadap tax avoidance. Jurnal Riset Akuntansi Dan Keuangan, 5(3), 1601-1624. https://doi.org/10.17509/jrak.v5i3.9223

Firmansyah, A., \& Estutik, R. S. (2020). Environmental responsibility performance, corporate social responsibility disclosure, tax aggressiveness: Does corporate governance have a role? Journal of Governance and Regulation, 9(4), 8-24. https://doi.org/10.22495/jgrv9i4art1

Firmansyah, A., \& Triastie, G. A. (2020). The role of corporate governance in emerging market: Tax avoidance, corporate social responsibility disclosures, risk disclosures, and investment efficiency. Journal of Governance and Regulation, 9(3), 8-26. https://doi.org/10.22495/jgrv9i3art1

Fontaine, C., Haarman, A., \& Schmid, S. (2006). The Stakeholder Theory.

Freeman, R. E. (2010). Strategic management: a stakeholder approach. Cambridge University Press.

Hidayat, K., Ompusunggu, A. P., \& Suratno, H. S. H. (2018). Pengaruh Corporate 
Social Responsibility terhadap Agresivitas Pajak dengan Insentif Pajak sebagai Pemoderasi (Studi pada Perusahaan Pertambangan yang Terdaftar di BEI). JIAFE (Jurnal Ilmiah Akuntansi Fakultas Ekonomi), 2(2), 39-58. https://doi.org/10.34204/JIAFE.V2I2.543

Iswari, P., Sudaryono, E. A., \& Widarjo, W. (2019). Political connection and tax aggressiveness: A study on the state-owned enterprises registered in Indonesia stock exchange. Journal of International Studies, 12(1), 79-92.

Jao, R., \& Pagalung, G. (2011). Corporate Governance, Ukuran Perusahaan, dan Leverage Terhadap Manajemen Laba Perusahaan Manufaktur Indonesia. JURNAL AKUNTANSI DAN AUDITING, 8(1), 43-54. https://doi.org/10.14710/JAA.8.1.43-54

Jensen, M. C., \& Meckling, W. H. (1976). Theory of the firm: Managerial behavior, agency costs and ownership structure. Journal of Financial Economics, 3(4), 305360. https:// doi.org/10.1016/0304-405X(76)90026-X

Khaoula, A., \& Mohamed Ali, Z. (2012). Demographic Diversity in the Board and Corporate Tax Planning in American Firms. Business Management and Strategy, 3(1). https://doi.org/10.5296/bms.v3i1.1851

Kim, C., \& Zhang, L. (2016). Corporate Political Connections and Tax Aggressiveness. Contemporary Accounting Research, 33(1), 78-114. https://doi.org/10.1111/1911-3846.12150

Kusumawati, W. T., \& Hardiningsih, P. (2016). The Effect Of Institusional Ownership And Corporate Social Responsibility To The Tax Aggressiveness. In Proceedings International Conference of Banking, Management, and Economics (ICOBAME) Journal, 2(1), 83-90.

Lanis, R., \& Richardson, G. (2013). Corporate social responsibility and tax aggressiveness: A test of legitimacy theory. Accounting, Auditing and Accountability Journal, 26(1), 75-100. https://doi.org/10.1108/09513571311285621/FULL/PDF

Lubis, I., Suryani, \& Anggraeni, F. (2018). Pengaruh kepemilikan Manajerial dan Kebijakan Utang Terhadap Agresivitas Pajak Pada Perusahaan Manufaktur. Jurnal Akuntansi Dan Keuangan, 7(2), 211-226.

Mardikanto, T. (2014). CSR Corporate Social Responsibility tanggung jawab sosial korporasi. Bandung: Alfabeta.

Martinus, J., Jiwandaningtyas, M. E., Firmansyah, A., \& Andriani, A. F. (2021). Penghindaran pajak pada industri barang konsumsi di Indonesia sebelum era pandemi covid19: ukuran perusahaan dan profitabilitas. Educoretax, 1(4), 291-300. https:/ / doi.org/10.54957/educoretax.v1i4.118

Mgbame, C. O., Chijoke-Mgbame, M. A., Yekini, S. ., \& Kemi, Y. C. (2017). Corporate social responsibility performance and tax aggressiveness. Journal of Accounting and Taxation, 9(8), 101-108. https:// doi.org/10.5897/JAT2017.0266

Mohanadas, N. D., Sallehhuddin, A., Salim, A., \& Pheng, L. K. (2019). CSR and tax aggressiveness of Malaysian listed companies : evidence from an emerging economy. January. https://doi.org/10.1108/SRJ-01-2019-0021

Noor, R. M., Fadzillah, N. S. M., \& Mastuki, N. (2010). Corporate Tax Planning: A Study On Corporate Effective Tax Rates of Malaysian Listed Companies. International Journal of Trade, Economics and Finance, 1(2), 189-193. 
https:// doi.org/10.7763/ijtef.2010.v1.34

Novitasari, S., Ratnawati, V., \& Silfi, A. (2017). Pengaruh Manajemen Laba, Corporate Governance dan Intensitas Modal terhadap Agresivitas Pajak Perusahaan. Jurnal Online Mahasiswa Fakultas Ekonomi Universitas Riau, 4(1), 1901-1914.

OECD. (2021). Revenue statistics in Asia and the Pacific 2021. In OECD Publishing Paris. $\quad$ http://www.oecd.org/tax/tax-policy/oecd-classification-taxesinterpretative-guide.pdf\%0Ahttps:// www.oecd-

ilibrary.org/taxation/revenue-statistics-in-asia-and-the-pacific2021_ed374457-en

Ortas, E., \& Gallego-Álvarez, I. (2020). Bridging the gap between corporate social responsibility performance and tax aggressiveness: The moderating role of national culture. Accounting, Auditing and Accountability Journal, 33(4), 825855. https://doi.org/10.1108/AAAJ-03-2017-2896

Pradnyawati, N. P., \& Suprasto, H. B. (2019). Pengaruh Good Corporate Governance Terhadap Agresivitas Pajak dengan Voluntary Disclosure Sebagai Variabel Pemoderasi. E-Jurnal Akuntansi, 26, 1132. https://doi.org/10.24843/eja.2019.v26.i02.p11

Prima, D., \& Pratiwi, R. (2015). Pengaruh Good Corporate Governance Terhadap Agresivitas Pajak Dimediasi Oleh Earnings Management Pada Perusahaan Yang Terdaftar Di Iicg. Jurnal Jurusan Akuntansi STIE, 1-10.

Priscilia, A., \& Agoes, S. (2019). Faktor Yang Mempengaruhi Agresivitas Pajak Perusahaan Manufaktur Yang Terdaftar Di BEI. Jurnal MultiParadigma Akuntansi, I(3), 979-987.

Ross, Stephen. A, Randolph W. Westerfield, Bradford D. Jordan, Joseph Lim, R. T. (2016). Pengantar Keuangan Perusahaan-edisi Asia 2. Jakarta: Salemba Empat.

Sadjiarto, A., Florencia, F., \& Nevanda, O. (2019). Effects of Political Connections and Corporate Governance on Tax Aggressiveness in Indonesian Service and Banking Sectors. Journal of Economics and Business, 2(1), 190-204. https:// doi.org/10.31014/aior.1992.02.01.79

Sari, D. L. (2017). Pengaruh Corporate Social Responsibility, Kepemilikan Mayoritas Dan Corporate Governance Terhadap Agresivitas Pajak (Studi pada Perusahaan Manufaktur yang Terdaftar di BEI Tahun 2011-2014). JOM Fekon, 4(1), 1813-1827.

Sari, D., \& Tjen, C. (2016). Corporate Social Responsibility Disclosure, Environmental Performance, and Tax Aggressiveness. International Research Journal of Business Studies, 9(2), 93-104. https:/ / doi.org/10.21632/irjbs.9.2.93104

Sari, P., \& Prihandini, W. (2019). Corporate Social Responsibility and Tax Aggressiveness in Perspective Legitimacy Theory. International Journal of Economics, Business and Accounting Research (IJEBAR), 3(04), 330-343. https://doi.org/10.29040/ijebar.v3i04.726

Seprini, S. (2016). Pengaruh Good Corporate Governance dan Corporate Sosial Responsibility Terhadap Tindakan Pajak Agresif. Jurnal Online Mahasiswa Fakultas Ekonomi, 3(1), 2238-2252.

Supriyono, V.-. (2011). Hubungan Antara Persepsi Dan Sikap Terhadap Pelaksanaan Corporate Social Responsibility. Jurnal Dinamika Manajemen, Vol 
2, No 2 (2011): September 2011 (DOAJ Indexed).

Swingly, C., \& Sukartha, I. M. (2015). Pengaruh karakter eksekutif, komite audit, ukuran perusahaan, leverage dan sales growth pada tax avoidance. E-Jurnal Akuntansi Universitas Udayana, 10(1), 47-62.

Tehupuring, R., \& Rossa, E. (2016). Pengaruh Koneksi Politik dan Kualitas Audit Terhadap Praktik Penhindaran Pajak di Lembaga Perbankan Yang Terdaftar di Pasar Modal Indonesia Periode 2012-2014. Prosiding Seminar Nasional INDOCOMPAC, 366-376.

Tjaraka, O. S. \&, \& Heru, H. (2013). Analisis Pengaruh Kepemilikan Manajerial Kebijakan Utang dan Ukuran Perusahaan terhadap Aggressiveness pada Perusahaan Manufaktur di Bursa Efek Indonesia Periode Tahun 2008-2010. Majalah Ekonomi Universitas Airlangga, 23(3).

Utami, C. T., \& Tahar, A. (2018). Pengaruh Corporate Social Responsibility, Kepemilikan Manajerial, Capital Intensity Dan Ukuran Perusahaan Terhadap Tax Aggressiveness : Studi Pada Perusahaan Jasa Sektor Property dan Real Estate yang Terdaftar di Bursa Efek Indonesia Tahun 2015-2017. Reviu Akuntansi Dan Bisnis Indonesia, 2(1), 39-50. https://doi.org/10.18196/rab.020119

Wahab, E. A. A., Ariff, A. M., Marzuki, M. M., \& Sanusi, Z. M. (2017). Political connections, corporate governance, and tax aggressiveness in Malaysia. Asian Review of Accounting, 25(3), 424-451. https://doi.org/10.1108/ARA-05-20160053/FULL/PDF

Wati, L. N. (2017). Board of commissioner's effectiveness on politically connected conglomerates: Evidence from Indonesia. Pertanika Journal of Social Sciences and Humanities, 25(November), 255-270.

Watts, R. L., \& Zimmerman, J. L. (1990). Positive accounting theory: a ten year perspective. The Accounting Review, 65(1), 131-156. https://www.jstor.org/stable/247880

Wicaksono, A. P. N. (2017). Koneksi politik dan aggresivitas pajak: fenomena di Indonesia. Akuntabilitas, 10(1), 167-180. https://doi.org/10.15408/AKT.V10I1.5833

Wijaya, D., \& Saebani, A. (2019). Pengaruh Pengungkapan Corporate Social Responsibility, Leverage, Dan Kepemilikan Manajerial Terhadap Agresivitas Pajak. Widyakala, 6(1), 55-76.

Winata, F. (2014). Pengaruh Corporate Governance Terhadap Tax Avoidance Pada Perusahaan Yang Terdaftar Di Bursa Efek Indonesia Tahun 2013. Tax E Accounting Review, 4 (1)(1), 1-11.

Yunistiyani, V., \& Tahar, A. (2017). Corporate Social Responsibility Dan Agresivitas Pelaporan Keuangan Terhadap Agresivitas Pajak Dengan Good Corporate Governance Sebagai Pemoderasi (Studi pada Perusahaan Manufaktur di Bursa Efek Indonesia). Jurnal Ilmiah Akuntansi, 2(1), 1-31. https://doi.org/10.23887/jia.v2i1.9610 